Fixed Point Theory, 23(2022), No. 1, 45-74

DOI: $10.24193 /$ fpt-ro.2022.1.04

http://www.math.ubbcluj.ro/ nodeacj/sfptcj.html

\title{
ON SYSTEM OF SPLIT GENERALISED MIXED EQUILIBRIUM AND FIXED POINT PROBLEMS FOR MULTIVALUED MAPPINGS WITH NO PRIOR KNOWLEDGE OF OPERATOR NORM
}

\author{
T.O. ALAKOYA*, A. TAIWO** AND O.T. MEWOMO*** \\ *School of Mathematics, Statistics and Computer Science, \\ University of KwaZulu-Natal, \\ Durban, South Africa \\ E-mail:218086823@stu.ukzn.ac.za, timimaths@gmail.com \\ ** School of Mathematics, Statistics and Computer Science, \\ University of KwaZulu-Natal, \\ Durban, South Africa \\ E-mail:218086816@stu.ukzn.ac.za, taiwo.adeolu@yahoo.com \\ *** School of Mathematics, Statistics and Computer Science, \\ University of KwaZulu-Natal, \\ Durban, South Africa \\ E-mail:mewomoo@ukzn.ac.za
}

\begin{abstract}
In this paper, we introduce the System of Split Generalized Mixed Equilibrium Problem (SSGMEP), which is more general than the existing well known split equilibrium problem and its generalizations, split variational inequality problem and several other related problems. We propose a new iterative algorithm of inertial form which is independent on the operator norm for solving SSGMEP in real Hilbert spaces. Motivated by the adaptive step size technique and inertial method, we incorporate self adaptive step size and inertial technique to overcome the difficulty of having to compute the operator norm and to accelerate the convergence of the proposed method. Under standard and mild assumptions on the control sequences, we establish the strong convergence of the algorithm, obtain a common solution of the SSGMEP and fixed point of finite family of multivalued demicontractive mappings. We obtain some consequent results which complement several existing results in this direction in the literature. We also apply our results to finding solution of split convex minimisation problems. Numerical example is presented to illustrate the performance of our method as well as comparing it with its non-inertial version.
\end{abstract}

Key Words and Phrases: Inertial algorithm, system of split generalized mixed equilibrium problems, fixed point problems, multivalued demicontractive mappings, strong convergence.

2020 Mathematics Subject Classification: 65K15, 47J25, 65J15, 90C33, 47H10.

\section{ACKNOWLEDGMENT.}

The authors sincerely thank the anonymous referee for his careful reading, constructive comments and fruitful suggestions that substantially improved the manuscript. 
The second author acknowledges with thanks the International Mathematical Union Breakout Graduate Fellowship (IMU-BGF) Award for his doctoral study. The third author is supported by the National Research Foundation (NRF) of South Africa Incentive Funding for Rated Researchers (Grant Number 119903). Opinions expressed and conclusions arrived are those of the authors and are not necessarily to be attributed to the IMU and NRF.

\section{REFERENCES}

[1] H.A. Abass, K.O. Aremu, L.O. Jolaoso, O.T. Mewomo, An inertial forward-backward splitting method for approximating solutions of certain optimization problems, J. Nonlinear Funct. Anal., 2020, (2020), Art. ID. 16, 20 pp.

[2] H.A. Abass, F.U. Ogbuisi, O.T. Mewomo, Common solution of split equilibrium problem and fixed point problem with no prior knowledge of operator norm, Politehn. Univ. Bucharest Sci. Bull. Ser. A Appl. Math. Phys., 80(2018), no. 1, 175-190.

[3] R.P. Agarwal, D. O'Regan, D.R. Sahu, Fixed Point Theory for Lipschitzian-type Mappings with Applications, Topological Fixed Point Theory and Its Applications, Springer-Verlag, New York, NY, 6, 2009.

[4] T.O. Alakoya, L.O. Jolaoso, O.T. Mewomo, A general iterative method for finding common fixed point of finite family of demicontractive mappings with accretive variational inequality problems in Banach spaces, Nonlinear Stud., 27(2020), no. 1, 1-24.

[5] T.O. Alakoya, L.O. Jolaoso, O.T. Mewomo, A self adaptive inertial algorithm for solving split variational inclusion and fixed point problems with applications, J. Ind. Manag. Optim., (2020), DOI:10.3934/jimo.2020152.

[6] T.O. Alakoya, L.O. Jolaoso, O.T. Mewomo, Modified inertia subgradient extragradient method with self adaptive stepsize for solving monotone variational inequality and fixed point problems, Optimization, (2020), DOI:10.1080/02331934.2020.1723586.

[7] T.O. Alakoya, L.O. Jolaoso, O.T. Mewomo, Two modifications of the inertial Tseng extragradient method with self-adaptive step size for solving monotone variational inequality problems, Demonstr. Math., (2020), doi.org/10.1515/dema-2020-0013.

[8] F. Alvarez, H. Attouch, An inertial proximal method for maximal monotone operators via discretization of a nonlinear oscillator with damping, Set-Valued Anal., 9(2001), 3-11.

[9] H.H. Bauschke, P.L. Combettes, A weak-to-strong convergence principle for Fejr-monotone methods in Hilbert spaces, Math. Oper. Res., 26(2001), no. 2, 248-264.

[10] A. Beck, M. Teboulle, A fast iterative shrinkage-thresholding algorithm for linear inverse problem, SIAM J. Imaging Sci., 2(2009), no. 1, 183-202.

[11] E. Blum, W. Oettli, From optimization and variational inequalities to equilibrium problems, Math. Stud., 63(1994), no. 14, 123-145.

[12] R.H. Chan, S. Ma, J.F. Jang, Inertial proximal ADMM for linearly constrained separable convex optimization, SIAM J. Imaging Sci., 8(2015), no. 4, 2239-2267.

[13] K. Cheawchan, A. Kangtunyakarn, The modified split generalized equilibrium problem for quasinonexpansive mappings and applications, J. Inequal. Appl., 2018(2018), Art. ID. 122.

[14] P.L. Combettes, A. Hirstoaga, Equilibrium programming in Hilbert spaces, J. Nonlinear Convex Anal., 6(2005), 117-136.

[15] A. Gibali, L.O. Jolaoso, O.T. Mewomo, A. Taiwo, Fast and simple Bregman projection methods for solving variational inequalities and related problems in Banach spaces, Results Math., 75(2020), Art. No. 179, 36 pp.

[16] Z. He, The split equilibrium problem and its convergence algorithms, J. Inequal. Appl., (2012), Art. ID. 162.

[17] D.V. Hieua, Parallel extragradient-proximal methods for split equilibrium problems, Math. Model. Anal., 21(2016), no. 4, 478-501.

[18] C. Huang, X. Ma, On generalized equilibrium problems and strictly pseudocontractive mappings in Hilbert spaces, Fixed Point Theory Appl., 2014(2014), Art. ID 145. 
[19] C. Izuchukwu, K.O. Aremu, A.A. Mebawondu, O.T. Mewomo, A viscosity iterative technique for equilibrium and fixed point problems in a Hadamard space, Appl. Gen. Topol., 20(2019), no. $1,193-210$.

[20] C. Izuchukwu, A.A. Mebawondu, O.T. Mewomo, A new method for solving split variational inequality problems without co-coerciveness, J. Fixed Point Theory Appl., 22(2020), no. 4, Art. No. 98,23 pp.

[21] C. Izuchukwu, G.N. Ogwo, O.T. Mewomo, An inertial method for solving generalized split feasibility problems over the solution set of monotone variational inclusions, Optimization, (2020), DOI:10.1080/02331934.2020.1808648.

[22] C. Izuchukwu, G.C. Ugwunnadi, O.T. Mewomo, A.R. Khan, M. Abbas, Proximal-type algorithms for split minimization problem in p-uniformly convex metric space, Numer. Algorithms, 82(2019), no. 3, 909-935.

[23] L.O. Jolaoso, T.O. Alakoya, A. Taiwo, O.T. Mewomo, A parallel combination extragradient method with Armijo line searching for finding common solution of finite families of equilibrium and fixed point problems, Rend. Circ. Mat. Palermo, 69(2020), no. 3, 711-735.

[24] L.O. Jolaoso, T.O. Alakoya, A. Taiwo, O.T. Mewomo, Inertial extragradient method via viscosity approximation approach for solving equilibrium problem in Hilbert space, Optimization, (2020), DOI:10.1080/02331934.2020.1716752.

[25] L.O. Jolaoso, K.O. Oyewole, C.C. Okeke, O.T. Mewomo, A unified algorithm for solving split generalized mixed equilibrium problem, and for finding fixed point of nonspreading mapping in Hilbert spaces, Demonstr. Math., 51(2018), no. 1, 277-294.

[26] L.O. Jolaoso, A. Taiwo, T.O. Alakoya, O.T. Mewomo, A unified algorithm for solving variational inequality and fixed point problems with application to the split equality problem, Comput. Appl. Math., 39(2020), no. 1, Paper No. 38, 28 pp.

[27] L.O. Jolaoso, A. Taiwo, T.O. Alakoya, O.T. Mewomo, A self adaptive inertial subgradient extragradient algorithm for variational inequality and common fixed point of multivalued mappings in Hilbert spaces, Demonstr. Math., 52(2019), 183-203.

[28] I. Karahan, L.O. Jolaoso, An iterative algorithm for the system of split mixed equilibrium problem, Demonstr. Math. 2020; 53: 309-324.

[29] K.R. Kazmi, S. Yousuf, Common solution to generalized mixed equilibrium problem and fixed point problems in Hilbert space, Rev. R. Acad. Cienc. Exactas Fis. Nat. Ser. A Mat. RACSAM, 113(2019), Art. ID 3699, https://doi.org/10.1007/s13398-019-00725-1.

[30] S.H. Khan, T.O. Alakoya, O.T. Mewomo, Relaxed projection methods with self-adaptive step size for solving variational inequality and fixed point problems for an infinite family of multivalued relatively nonexpansive mappings in Banach spaces, Math. Comput. Appl., 25(2020), Art. 54.

[31] M.A.A. Khan, Y. Arfat, A.R. Butt, A shrinking projection approach for split equilibrium problems and fixed point problems in Hilbert spaces, Politehn. Univ. Bucharest Sci. Bull. Ser. A Appl. Math. Phys., 80(2018), no. 1, 33-46.

[32] J.K. Kim, N. Buong, An iteration method for common solution of a system of equilibrium problems in Hilbert spaces, Fixed Point Theory Appl., 2011(2011), Art. ID 780764

[33] D. Lorenz, T. Pock, An inertial forward-backward algorithm for monotone inclusions, J. Math. Imaging Vision, 51(2015), no. 2, 311-325.

[34] P.E. Maingé, Approximation methods for common fixed points of nonexpansive mappings in Hilbert spaces, J. Math. Anal. Appl., 325(2007), 469-479.

[35] P.E. Maingé, Convergence theorems for inertial KM-type algorithms, Comput. Appl. Math., $\mathbf{2 1 9}(2008)$, no. 1, 223-236.

[36] A. Moudafi, M. Oliny, Convergence of a splitting inertial proximal method for monotone operators, J. Comput. Appl. Math., 155(2003), no. 2, 447-454.

[37] C.C. Okeke, C. Izuchukwu, O.T. Mewomo, Strong convergence results for convex minimization and monotone variational inclusion problems in Hilbert spaces, Rend. Circ. Mat. Palermo, 69(2020), no. 2, 675-693.

[38] N. Onjai-uea, W. Phuengrattana, On solving split mixed equilibrium problems and fixed point problems of hybrid-type multivalued mappings in Hilbert spaces, Journal of Inequalities and Applications, 2017(2017), no. 1, p. 137. 
[39] O.K. Oyewole, H.A. Abass, O.T. Mewomo, Strong convergence algorithm for a fixed point constraint split null point problem, Rend. Circ. Mat. Palermo, (2020), DOI:10.1007/s12215-02000505-6.

[40] W. Phuengrattana, K. Lerkchaiyaphum, On solving the split generalized equilibrium problem and the fixed point problem for a countable family of nonexpansive multivalued mappings, Fixed Point Theory Appl., 2018(2018), 1-6.

[41] B.T. Polyak, Some methods of speeding up the convergence of iteration methods, Politehn. Univ. Bucharest Sci. Bull. Ser. A Appl. Math. Phys., 4(1964), no. 5, 1-17.

[42] X. Qin, S.M. Kang, Y.J. Cho, Convergence theorems on generalized equilibrium problems and fixed point problems with applications, Proc. Estonian Acad. Sci., 58(2009), 170-318.

[43] S. Saejung, P. Yotkaew, Approximation of zeros of inverse strongly monotone operators in Banach spaces, Nonlinear Anal., 75(2012), 742-750.

[44] Y. Song, Y.J. Cho, Some note on Ishikawa iteration for multivalued mappings, Bull. Korean Math. Soc., 48(2011), no. 3, 575-584.

[45] S. Suantai, P. Cholamjiak, Y.J. Cho, W. Cholamjiak, On solving split equilibrium problems and fixed point problems of nonspreading multi-valued mappings in Hilbert spaces, Fixed Point Theory Appl., (2016), Art. ID 1, 35.

[46] A. Taiwo, T.O. Alakoya, O.T. Mewomo, Halpern-type iterative process for solving split common fixed point and monotone variational inclusion problem between Banach spaces, Numer. Algorithms, (2020), DOI:10.1007/s11075-020-00937-2.

[47] A. Taiwo, L.O. Jolaoso, O.T. Mewomo, Parallel hybrid algorithm for solving pseudomonotone equilibrium and split common fixed point problems, Bull. Malays. Math. Sci. Soc., (2019), DOI: 10.1007/s40840-019-00781-1.

[48] A. Taiwo, L.O. Jolaoso, O.T. Mewomo, Viscosity approximation method for solving the multipleset split equality common fixed-point problems for quasi-pseudocontractive mappings in Hilbert Spaces, J. Ind. Manag. Optim., (2020), DOI:10.3934/jimo.2020092

[49] A. Taiwo, L.O. Jolaoso, O.T. Mewomo, A. Gibali, On generalized mixed equilibrium problem with $\alpha-\beta-\mu$ bifunction and $\mu-\tau$ monotone mapping, J. Nonlinear Convex Anal., 21(2020), no. $6,1381-1401$.

[50] A. Taiwo, A.O.-E. Owolabi, L.O. Jolaoso, O.T. Mewomo, A. Gibali, A new approximation scheme for solving various split inverse problems, Afrika Mat., (2020), DOI:https://doi.org/10.1007/s13370-020-00832-y.

[51] G.C. Ugwunnadi, B. Ali, Approximation methods for solutions of system of split equilibrium problems, Adv. Oper. Theory, 2(2016), 164-183.

[52] Y. Yao, M.A. Noor, S. Zainab, Y.C. Liou, Mixed equilibrium problems and optimization problems, J. Math. Anal Appl., 354(2009), no. 1, 319-329.

[53] S. Zhang, Generalized mixed equilibrium problem in Banach spaces, Appl. Math. Mech. (English Edition) 30(2009), 1105-1112.

Received: March 7, 2020; Accepted: November 29, 2020. 